\title{
The Multi-Level Marketing Practice in Taiwan
}

\author{
Professor Carol Hwa-Meei Liou \\ Graduate Institute of Technology Management \\ National Taiwan University of Science and Technology \\ 43, Sec. 4, Keelung Rd., Taipei 10607, Taiwan
}

\section{Introduction}

The multi-level marketing (MLM) industry in Taiwan started with metamorphic multilevel marketing being introduced into Taiwan by Japanese businessmen. There did not exist any laws then to regulate such activities, such as inthe case of the Zhōnghuábăokāngcüjinhuiin 1976 and the case of the Tai Gua company in 1981. The MLM concept was jointly created by Lee Mytinger and William Casselberry in the United States in 1945 (Fair Trade Commission, 2016: 3-4). Taiwan is the second largest direct selling market in Asia and has the highest population density for direct selling in the world(Lin, 2015:11). The World Federation of Direct Selling Associations (WFDSA)is currently the world's largest organization in the MLM industry (Lin, 2018: 56).

In 2016, there were a total of 2.737 million people involved in the MLM business(Fair Trade Commission, 2018a). In 2017, there were 38 dispositions of cases of illegal MLM which were fined a total of NT $\$ 15.8$ million (Fair Trade Commission, 2018a).

The participants in the MLM industry have no employment, delegation, partnership or agency relationship with the MLM businesses(Fair Trade Commission, 2016). The participants have financial and personal independence, and also play the role of the "operator", "manager", and "consumer" at the same time(Lin, 2017: 12). The bonus and reward system is the main incentive for the participants to join the MLM industry. For example, in 2016 the commission (bonus) in the MLM business accounted for $38.87 \%$ of their total turnover(Fair Trade Commission, 2016).

In 2016, when MLM businesses were asked about their views on the future of the industry, the top issue they highlighted was concern about the impact of a market downturn, followed by the damage caused by illegal MLM activities.A total of 161 MLM businesses took part in the survey, accounting for $47.63 \%$ of the total MLM businesses. In addition, in 2016, the MLM businesses thought that the area that they needed assistance the most or where they frequently encountered problems was in seeking advice about the Multi-Level Marketing Supervision Act and relevant cases (Fair Trade Commission, 2016).

The following three figures show the current scale of the MLM industry in Taiwan: the MLM business has shown steady growth in Taiwan.

Figure1: Total Sales

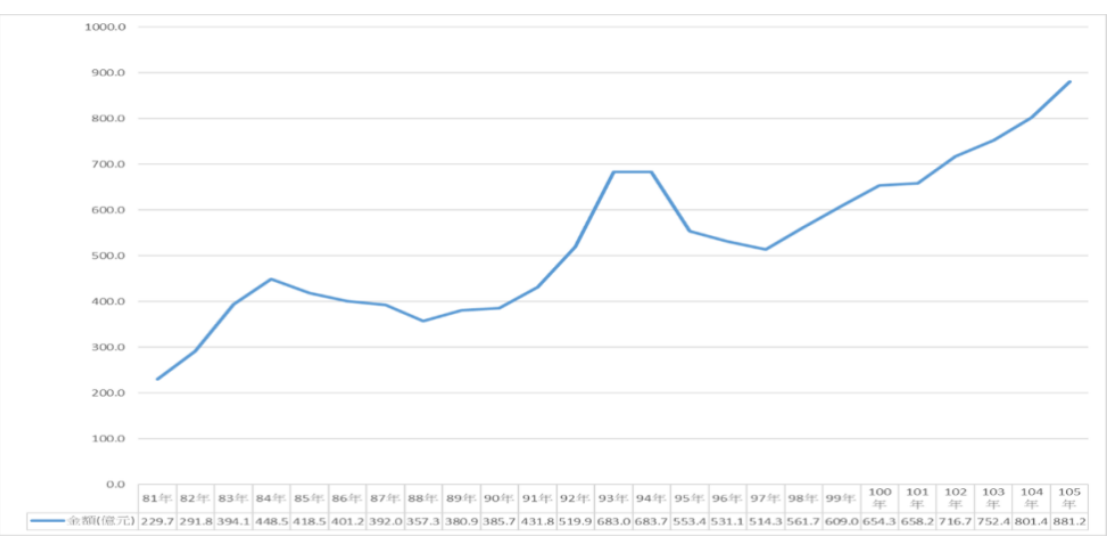

Source: Fair Trade Commission (2016: 26) 
Figure 2: Number of MLM Participants

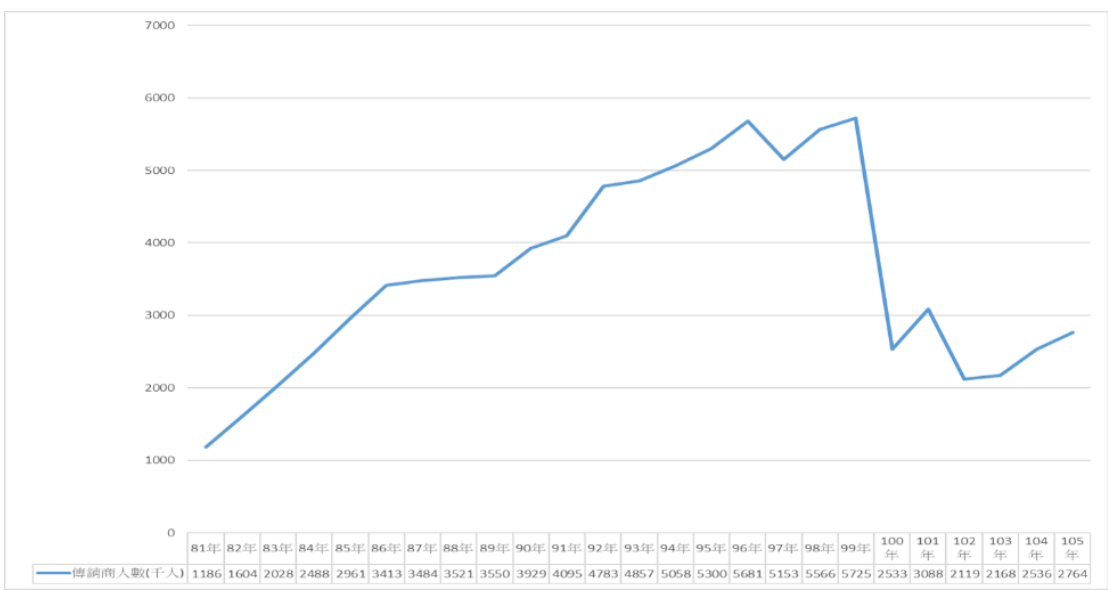

Source: Fair Trade Commission (2016: 26)

Figure3: Number of MLM Businesses

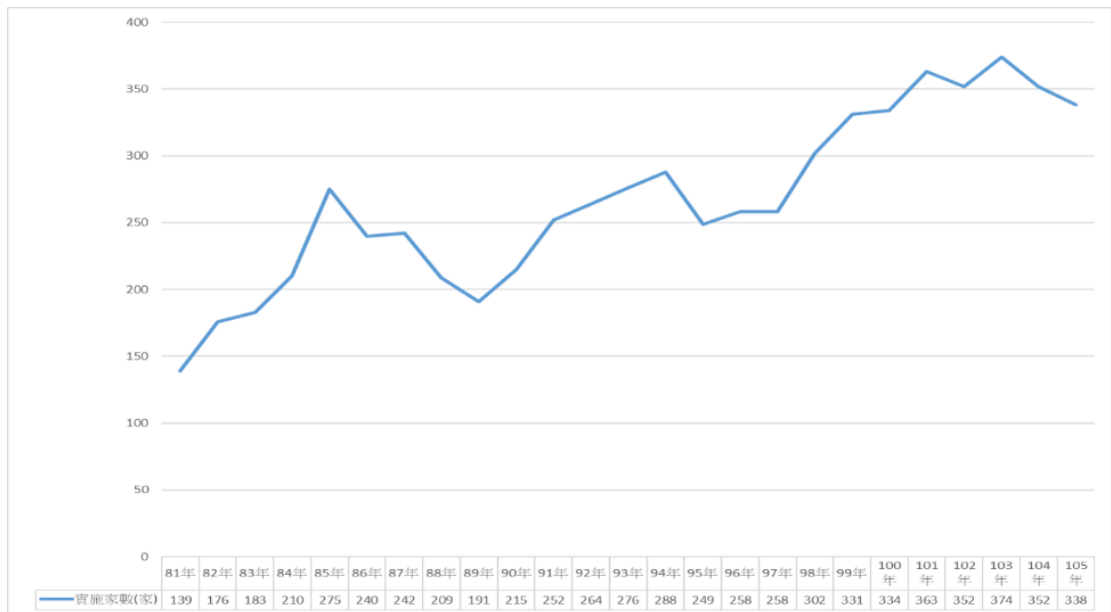

Source: Fair Trade Commission (2016: 26)

\section{History}

The draft Fair Trade Act developed by scholars in 1982 did not seek to regulate MLM. MLM regulations were first introduced in the Fair Trade Act in 1992, and because MLM practices are related to business transactions(Liao, 2013: 1358), a legislative approach that merged the two was adopted. At that time, MLM was defined in Article 8 of the Fair Trade Act and in the prohibition of improper MLM practices in Article 23, as well as in the corresponding penalties laid down in Article 35.The Fair Trade Commission was also authorized under the Fair Trade Act to issue an executive order to find a way to manage the MLM industry. This was the first time that a law to regulate MLM activities was enacted in Taiwan. Since then, the Fair Trade Commission has accumulated more than 20 years of practical experience in managing the MLM industry.

As the MLM industry was regulated by administrative orders, it was easy toresult inviolations of the principle of legal reservations in the administrative law. When the Fair Trade Act was amended in 1999, the regulations for several important provisions regarding MLM management were thus repositioned in the Fair Trade Act, namely from Article 23-1 to Article 23-4 in the then-Fair Trade Act. As the nature of the Fair Trade Act is to regulate the competitive behavior of businesses, and since MLM does not constitute competitive behavior, it is therefore not suitable to use the Fair Trade Act to regulate MLM industries(Liao, 2013: 1358; Lin T. Y., 2004: 134).The legislators thereafter created a separate legislation to regulate MLM industries, and the Multi-Level Marketing Supervision Act was officially enacted on 29 January 2014, with 41 articles. From this point onwards, the MLM industry was managed by a special law. 
Although the content of the current Multi-Level Marketing Supervision Act was mostly adapted fromthe Fair Trade Act and the MLM Management Regulations asauthorized under the Fair Trade Act, there were also drastic changes made to some of the provisions. As legislated under the Multi-Level Marketing Supervision Act, the competentauthority of the act is the Fair Trade Commission.

\section{Legal Aspects}

Multi-level marketing typically comprises at least a two-level structure, whichdoes not include the MLM business itself (Fair Trade Commission, 2016: 20). Management of the MLM industry is basically done via the MLM businesses notifying the competent authority of their activities, and such notification must be done prior to any MLM activities. If there are any changes after the activities are carried out which are different from what was originally notified to the authorities, a notification must also be made before the amendment is carried out; and if the MLM activities are stopped, the authorities must also be notified before the activities are ceased. Products promoted and sold by MLM businesses are required to separately obtain permission from the competent authority of the specific industry(such as the Ministry of Health and Welfare) before these products could be promoted and sold, and then when notifying the Fair Trade Commission, it is also necessary to obtain a proof of the permission obtainedfrom the competent authority of the specific industry. It is illegal to carry out MLM activities without notifying the competentauthority, but even where businesses have notified the competentauthority, it does not mean that their marketing activities are legal, and they will still be judged on a case-by-case basis. Furthermore, as long as MLM activities are actually engaged in, whether or not the competentauthority is notified, these activities will still be subjected to the regulation under the Multi-Level Marketing Supervision Act (Fair Trade Commission, 2016: 26).

If the MLM business capital reaches a certain amount or if the turnover from the previous year reaches the amount as determined by the competentauthority, it would be mandatory under the Multi-Level Marketing Supervision Act for the company's financial statement to be audited by an accountant.

Every year, the competentauthority will publish on its website a MLM industry development status report in the middle of the year. The reporting period of the latest issue of the MLM Industry Development Status Report 2016 (Fair Trade Commission, 2016: 26)is from January to December 2016, and the report is based on the notifications made by MLM businesses to the competentauthority.

The Multi-Level Marketing Protection Foundation is a unique innovation ofTaiwan, and can be described as a world's first. The Legislative Yuan had initially consulted the model of the Financial Ombudsman Institution under the Financial Consumer Protection Act (accordingto the legislative explanation for the Multi-Level Marketing Supervision Act) to set up this foundation, the purpose of which is to protect the MLM participants, by establishing a set of civil dispute mediation mechanism between the MLM businesses that have been complained of,and theMLM participants. The foundation was set up in January 2014 and began operations in December 2014. The source of funds comes from the membership and annual fees that the MLM businesses and participants are required to pay when they join the foundation, and the fees are approved and announced by the competentauthority on an annual basis. The annual fee for every participant was NT\$200 in 2016. However, in order to encourage MLM participants to join the Multi-Level Marketing Protection Foundation, the annual fees for the MLM participantsin the latest 2017 announcement was NT\$0. An MLM business which has completed its notification but still violated its obligations tojoin the foundation and thereby make payments will be subjected to administrative penalties. When the MLM business and participants agree to mediation, this is only effective as a private settlement agreement. The Multi-Level Marketing Protection Foundation will compensate the participantsof up to NT $\$ 300,000$, and recover the damages from the MLM business based on its subrogation relationship(Chen,2016: 99). The Multi-Level Marketing Protection Foundation has a mediation committee to handleMLM disputes, which currently has several mediation committee members. As there are no restrictions to the investment threshold and regulations on security deposits when setting up a MLM business (Lin, 2018: 62), there is a real need to strengthen the protection of the MLM participants.

MLM and the franchise system are both a form of marketing. Other than the promotion and selling of goods, bonuses, commission and other financial incentives can be earned by introducing others to join the MLM business. However, in the franchise system, the relationship between the franchise store and franchise owner is a single-level relationship and not that of a multilayer sales organization(Lin, T. C./chief editor, 2015: 9; Fair Trade Commission, 2010). 
Under Article 19 of the Fair Trade Act, on the regulation restricting resale prices, the MLM business is in principle not allowed to limit the sales prices of the MLM participant.

\section{Metamorphic Multilevel Marketing}

Metamorphic multilevel marketing has caused major social problems in many countries, including Taiwan. According to the latest statistics, there were a total of 28 cases of metamorphic multilevel marketing and illegal deposit taking that weretransferred to the prosecutor by the Fair Trade Commission in 2017, including the metamorphic multilevel marketing cases (Yīnuò, etc.) investigated by the Fair Trade Commission, and the public reporting of illegal deposit taking activities (Héyínghuì, etc.)(Fair Trade Commission, 2018a).Metamorphic multilevel marketing is strictly prohibited and does not have any legality. (Hwang, 2014: 349-350)

Metamorphic multilevel marketing is known as the Ponzi Scheme or Headhunter in Taiwan, the pyramid scheme in the United States, Canada, the United Kingdom, and Australia, the Snowball System/ Schneeballsystem in Europe, andthe wireless chain association or Rat Club in Japan (Wu\& Shen, 2014: 185-186). There are similar naming systems in China and Hong Kong (Chen, 2018: 154-155).

Metamorphic multilevel marketing is defined in Article 18 of the Multi-Level Marketing Supervision Act and Article 6 of the enforcement rules of the Multi-Level Marketing Supervision Act. Article 18 states: "Multi-levels sales enterprises shall have participants engaged in promoting and selling goods or service in reasonable market price as their major income, instead of earning mainly by introducing new participants." With regard to the interpretation of the constitutive elements of Article 18, the Fair Trade Commission has issued an Interpretation Order (Fair Trade Commission, 2005).

The "main" identification criteria istheobtaining of bonuses by MLM participants mainly from introducing others to enter the business, and not from the sales promotion of products. In general, the bonuses of the participants come from three sources: (1) introducing others to join the business, (2) reasonable profit from the promotion and sales of goods and services, and (3) a combination of both the characteristics of (1) and (2). If A's bonus amount accounts for more than $50 \%$ of the total incentive pay, it can be considered that the "main" bonus was "mainly" dependent onthe introduction of others into the business(Yang, 2016).

For the "fair market value" criteria, if it is not easy to clearly divide the income of the participants according to the two parts as stated in the previous paragraph, the judgment is done by looking at whether the product price is at the "fair market value". In such cases, there are two situations: (1) where the market has similarly competitive goods or services: for goods and services which have similar variants locally or abroad or are of similar prices, the quality should be used as the main reference point. When the interest rates of MLM businesses are compared with the interest rates of the same or similar products in non-MLM businesses, other consideration factors would include unique skills and service levels. (2) Where the market does not have competitive goods or services: it will be determined on a case-by-case basis.

The general description of the Multi-Level Marketing Supervision Actis as follows: "There has beena rise of MLM activities, and where there were unscrupulous individuals who made use of metamorphic multilevel marketing to perform frauds, this has caused serious social problems, and there is a need to further investigate and take preventiveaction. Therefore, it is necessary for the current legislature to introduce a complete Multi-Level Marketing Supervision Act, to strengthen the management and supervision of multi-level marketing activities." The main legislative intentof Articles 18 and 19 of the Multi-Level Marketing Supervision Act was: "The main income source of MLM participants comes from the introduction of others to join the MLM business, and because the participants would later not be able to solicit enough people to join, and suffer financial loss, this will cause serious social problems, which the act expressly prohibits; and it is a common practice by MLM businesses to take advantage of others by collecting fees and retaining them, as well as by using other tactics, and to engage in metamorphic multilevel marketing or to conduct scams to accumulate wealth, etc., through improper MLM activities, which the act expressly prohibits."

Pertaining to metamorphicMLM-related issues, the Grand Justices of the Judicial Yuanissued J.Y. Interpretation, No.602, which stated under theholding: "Article 23, Paragraph 1, of the Fair Trade Law, enacted and implemented on February 4, 1991, prescribes that, "No multi-level sale shall be conducted if the participants thereof receive commissions, bonuses or other economic benefits mainly from recruiting others to join, rather than from the marketing or sale of the goods or services at reasonable market prices." 
The terms, "mainly" and "reasonable market price", used in the foregoing quoted paragraph are ascertainable by judging the sources of participant's economic benefits and the prices of participants' marketing or sale of the goods or services. Besides, since the management plan, structure, and coordination of sales are mostly set up by the enterprises conducting multi-level sales, those who engage in illegal multi-level sales are aware of the economic benefits mainly coming from recruiting others to join rather than from the marketing or sale of the goods or services at reasonable market prices, and such facts are not unforeseeable to them, according to their professional knowledge and common sense. Thus, the standards provided by the foregoing quoted paragraph are subject to judicial review as they are provided for the courts to ascertain and judge against the facts, and hence the foregoing quoted paragraph is consistent with the principle of clarity and definiteness of law. Moreover, under Article 35 of the same law, those who violate the regulations of the foregoing quoted paragraph are subject to criminal punishment fitting the nature of the crime [as Article 23, Paragraph 1, becomes the element of the crime prescribed The meaning of this clause is unclear]. Article 35 is consistent with the principle of clarity and definiteness of law and the principle of the punishment fitting the crime, both derived from nullumcrimen sine lege, nullapoena sine lege, and is necessary to maintain social transactional orders, to enhance market functions and to facilitate economic stability and prosperity. Accordingly, Article 23, Paragraph 1, and Article 35 are neither in contravention to Article 23 of the Constitution, nor to the constitutional guarantees of personal freedom and property rights under Articles 8 and 15 of the Constitution (Judicial Yuan, 2005)."

After the J.Y. Interpretationwas announced, the competentauthority acted to amend the above-mentioned Interpretation Order in 2005, in accordance with the opinionsof the J.Y. Interpretation.

As for illegal deposit taking, if the MLM business is involved in the sales promotion of goods and services, but earns profits from increasing the headcount invited into its business instead of from the sales promotion of goods and services, thisisprecisely what the Multi-Level Marketing Supervision Act aims to target. If the MLM business engages in zero sales promotion of goods and services but is only absorbing new members, then this comesunder the Banking Act and is within the scope of criminal punishment. (Lin, 2018: 58)

\section{Online Multi-Level Marketing}

For online MLM, there were 168 MLM businesses which were engaged in Internet marketing in 2016, comprising $49.70 \%$ of the total number of MLM businesses. Internet marketing includes Internet (online) shopping, or the setting up of an online mall for participants to purchase items at, or both of the above activities. Currently, Internet marketing in the MLM market is mainly composed of Internet shopping. Most of the online shopping malls are set up by the MLM business themselves. In a few cases, they are set up by the MLM businessesin collaboration with others. (Fair Trade Commission, 2016; Liu, 2018: 65)

There is a higher riskin using the Internet to conductMLM activities and in recruiting members. (Fair Trade Commission, 2016: 24) The Fair Trade Commission has ever received many disposition cases against online MLM."According to statistics released on the disciplinary action taken by the Fair Trade Commission on online MLM businesses, from the cases of MLM violations, including MLM businesses which use online advertising, online marketing and those who use the Internet to make purchases, as well as those who use the Internet to invite others to join MLM businesses or promote MLM businesses, since theMulti-Level Marketing Management Lawwas implemented, and during the period when the Fair Trade Act was amended in 1999, up until the time before the Multi-Level Marketing Management Law was implemented in 2013, the Fair Trade Commission would analyze the statistics of disposition cases with the distribution of the provisions during the two periods. After the implementation of the Multi-Level Marketing Management Law, the Fair Trade Commission had carried out dispositions against 27 cases of online-related MLM activities, with the regulations contravened spread across articles 6, 7, 10, and articles 14, 20 and 24, with highest number of violators contravening Article 6, for not notifying the competentauthority prior to commencing MLM activities, and for not giving notifications about any amendments. Prior to the implementation of the Multi-Level Marketing Management Law in 2013, and after the amendment of the Fair Trade Act in 1999, for the online MLM violators of the Multi-Level Marketing Management Regulation, there were the highest number of violators for articles 5 and 12, in not giving notifications prior to commencing MLM activities, and in not entering into an agreement with participants, respectively. Since the Fair Trade Act was promulgated in 1990, there were online MLM businesses which faced dispositions by the Fair Trade Commission as early as 2000, though there were not many users. And around 2010 when Internet use became more mature, the number of cases increased significantly."(quotation from Yang, 2018). 


\section{Penalties}

Regarding the penalties for MLM businesses which break the law, in general violators are subjected to administrative responsibility under the Multi-Level Marketing Supervision Act, but if it involves metamorphic multilevel marketing, this will result in criminal liability. In terms of criminal punishment, the Banking Act was referenced during the amendment of the Multi-Level Marketing Supervision Act, which increased the criminal responsibility. The original provision imposed a term of imprisonment of up to three years under the Fair Trade Act. After the amendment, the current law was changed to a term of imprisonment of up to 7 years, and a fine of not more than NT $\$ 100$ million. What is special about the amendment is that for the penalty for metamorphic multilevel marketing, other than punishing the offenders of the crime, the legal person of the offenders will also be fined the same amount. Furthermore, if the MLM business violates both the administrative and criminal laws at the same time, according to Article 26 of the Administrative Penalty Law, criminal punishment takes precedence, and the case will be transferred from the competentauthority to the prosecutor.

The administrative penalties for MLM businesses who are involved inmetamorphic multilevel marketingactivitiesare such that they would be ordered by the Fair Trade Commissionto disband, shut down or to cease operations for up to six months. For example, in 2002, the Fair Trade Commission (2002) fined an MLM business NT\$25 million and ordered it to shut down(Wu\& Shen, 2014).

Prior to 2002, even where participants were involved in metamorphic multilevel marketing, the Fair Trade Commission would only penalize the MLM businesses. However, after 2002, participants were also included in the scope for administrative penalties. For example, in the case of a fire prevention and safety association (Zhōnghuáfánghuōānquánxiéhui), whereparticipants were found to be actively engaged in metamorphic multilevel marketing(Fair Trade Commission, 2002), Article 18 of the Multi-Level Marketing Supervision Act was also applied to them. (Fair Trade Commission,2016: 22)

If violators are dissatisfied with the dispositions meted out to them by the Fair Trade Commissionunder the MultiLevel Marketing Supervision Act, they would have to appeal to the Executive Yuan. If they are dissatisfied with the outcome of the appeal, they would have to apply for administrative litigation at the administrative court under the district courts or the higher administrative courts for relief. (Cheng\& Chen, 2015: 95)

\section{Statistics of Case Studies}

We look at an example of an actual case (Table1): "The violator who used the mobile phone number of a participant to sell MLM products should have taken the initiative to contact the MLM participants and approach the telecommunication companies to handle the situation"; "the MLM participant who joined the violator under the tactic of applying for a new mobile number line, other than signing a contract with the accused, should also sign a contract with the third-party telecommunications company, to complete the procedures and receive the status of an MLM participant. The MLM business would obtain a commission from the telecommunications company which it should use as the bonuses for the participants. If the participant joined the accused by using a mobile phone number, then on the basis of the rights and obligations of the payment of MLM products, the contract needed to be terminated, and the termination should be based on the cancellation of the mobile phone contract. After receiving the notice of the cancellation of the contract from the MLM participant, the business should also complete the cancellation of the contract with telecommunications company. Once the violator received the cancellation of the contract from the participant, the violator should have assisted the participant to cancel his or her contract with the telecommunications company, and this has to be balanced with the obligations of the violator under articles 20 and 21 of the Multi-Level Marketing Supervision Act. Paragraph 2 of Article 22 under the Multi-Level Marketing Supervision Act also states: "MLM products are provided by third parties, when the MLM business exercises its right to terminate the agreement based on the previous two provisions, the MLM business would have to handle the returns and buyback according to the previous two provisions, and also bear the liquidated damages from the rescinding or termination of the contract", "within 30 days of the cancellation of the contract with the violator of the MLM business, the business has to voluntarily withdraw and return the goods in accordance with the law, as this is a violation of Article 24 of the Multi-Level Marketing Supervision Act as well as Article 20, paragraph 2, and Article 21, paragraph 2 of the same law." A total fine of NT\$1 million was meted out for this case (quotation from Fair Trade Commission, 2014). 


\section{Conclusion}

Multi-level marketing has been in existence in Taiwan for more than 30 years. From a management perspective, Taiwan also has over 25 years of government regulatory experience. In addition, the number of people who are engaged in MLM activities is as high as 10 percent of the Taiwanese population. The turnover of some MLM businesses can be in the range of hundreds and millions of dollars, which is an industry not to be underestimated. What is of concern to the competentauthorities are the metamorphic multilevel marketing cases which affects many of their members, and the amount of money involved is also very high, which has resulted in social issues and requires MLM activities to be sanctioned by law. In the age of the Internet, MLM industries have used the Internet and online malls to expand their businesses and sell their products, and this is becoming increasingly prevalent in Taiwan. MLM businesses would often also self-regulate to monitor the behavior of the industryitself and its participants, so as to protect the rights of the consumer.(Taiwan R.O.C Direct Selling Association, 2017) Based on official statistics, the MLM industry is a stable growth industry and it is thus worthwhile to continue to invest in the research of the regulation and management of the MLM industry. With the rise of emerging technologies, for example, in how more attention is paid to the use of artificial intelligence in MLM businesses, how such technologies would have an impact on MLM in future is a topic worth paying attention to.

\section{References}

Chen, G. F. (2016).Comparison and Review on the Dispute Resolution Regulated in Multi-Level Marketing Supervision Act. Ft Law Review, 207, 94-101.

Chen, T. C. (2018).Identification of the Practical Problems of Metamorphic MLM Legal Issues.Taiwan Law Journal issue, 341, 154-165.

Cheng, F. J. \& Chen, W. S. (2015). Research on MLM Illegal Activities. Fair Trade Quarterly, 24(1), 93-143.

Fair Trade Commission (2005).The Interpretation of and Legislation on the Multi-Level Marketing SupervisionAct.Interpretation Order(Gōngyánshi), No. 008.

Fair Trade Commission (2010).Disposition (Gōngchùzi), No. 099055.

Fair Trade Commission (2002).Disposition (Gōngchùzi), No. 091028.

Fair Trade Commission (2014).Disposition (Gōngchùzi), No. 103033.

Fair Trade Commission (2016).Get to know the Multi-Level Marketing Management Law. Taipei: Fair Trade Commission.

Fair Trade Commission (2016).MLM Business Development StatusReport 2016.[Online] Available: https://www.ftc.gov.tw/internet/main/doc/docDetail.aspx?uid=488\&docid=15126 (August 28, 2018).

Fair Trade Commission(2018a).Mid-Year Outcome Report 2017.[Online] Available: https://www.ftc.gov.tw/upload/26129266-fa80-4e2d-8c04-72cf3821e615.doc(August 28, 2018).

Fair Trade Commission(2018b).Statistical Report 2017. [Online] Available: https://www.ftc.gov.tw/upload/ba20f0da-5f88-4f58-9c50-f3f73bc79efc.pdf(August 28, 2018).

Hwang, M. J. (2014).Series2ndof Research on the Explanation of the Multi-Level Marketing Management Law. Commissioned Research Report, Taipei: Fair Trade Commission.

Judicial Yuan (2005).J.Y. Interpretation, No. 602.[Online] Available: https://www.judicial.gov.tw/constitutionalcourt/EN/p03_01.asp?expno=602(August 28, 2018).

Liao, Y. N. (2013).Draft Review of the Multi-Level Marketing SupervisionAct.The Law Monthly, 64(9), 121-126.

Lin, T. Y. (2004). The Legislative Review of the Multi-Level Marketing Management Law). Fair Trade Quarterly, 12(4), 131-163.

Lin, T. C. \& Lin, Y. N./chief editor (2017).Q\&A of the Practical Issues of the Direct Selling Law. Taipei: ShuChuan Publishing House.

Lin, T. C./ Chief Editor (2015).Direct Selling Law. Taipei: Wu-Nan.

Lin, Y. N. (2018). The True Colors of MLM.Taiwan Law Journal issue, 340, 56-63.

Liou, H. M. (2018).Metamorphic MLM Legal Issues. Taiwan Law Journal issue, 340, 64-68.

Taiwan R.O.C Direct Selling Association (2017).2017 Instructor Training Manual. Taipei: Taiwan R.O.C Direct Selling Association.

Wu, S. M. \& Shen, L. Y. (2014). The New Era of the Multi-Level Marketing SupervisionAct. The Taiwan Law Review, 231, 170-193.

Yang, S.Y(2016).MLM brief report.Taipei: National Taiwan University of Science and Technology.

Yang, G. X. (2018).The Regulation of Multi-level Marketing on the Internet. Master's Thesis, Taipei: Graduate Institute of Technology Management, National Taiwan University of Science and Technology. 
ISSN 2219-1933 (Print), 2219-6021 (Online)（C) Center for Promoting Ideas, USA www.ijbssnet.com

Table1: Ruling Decisionsof Multi-Level Sales Enterprises- by Articles1992 - 2017

Supervisory Regulations Governing Multi-level SalesUnit:Case

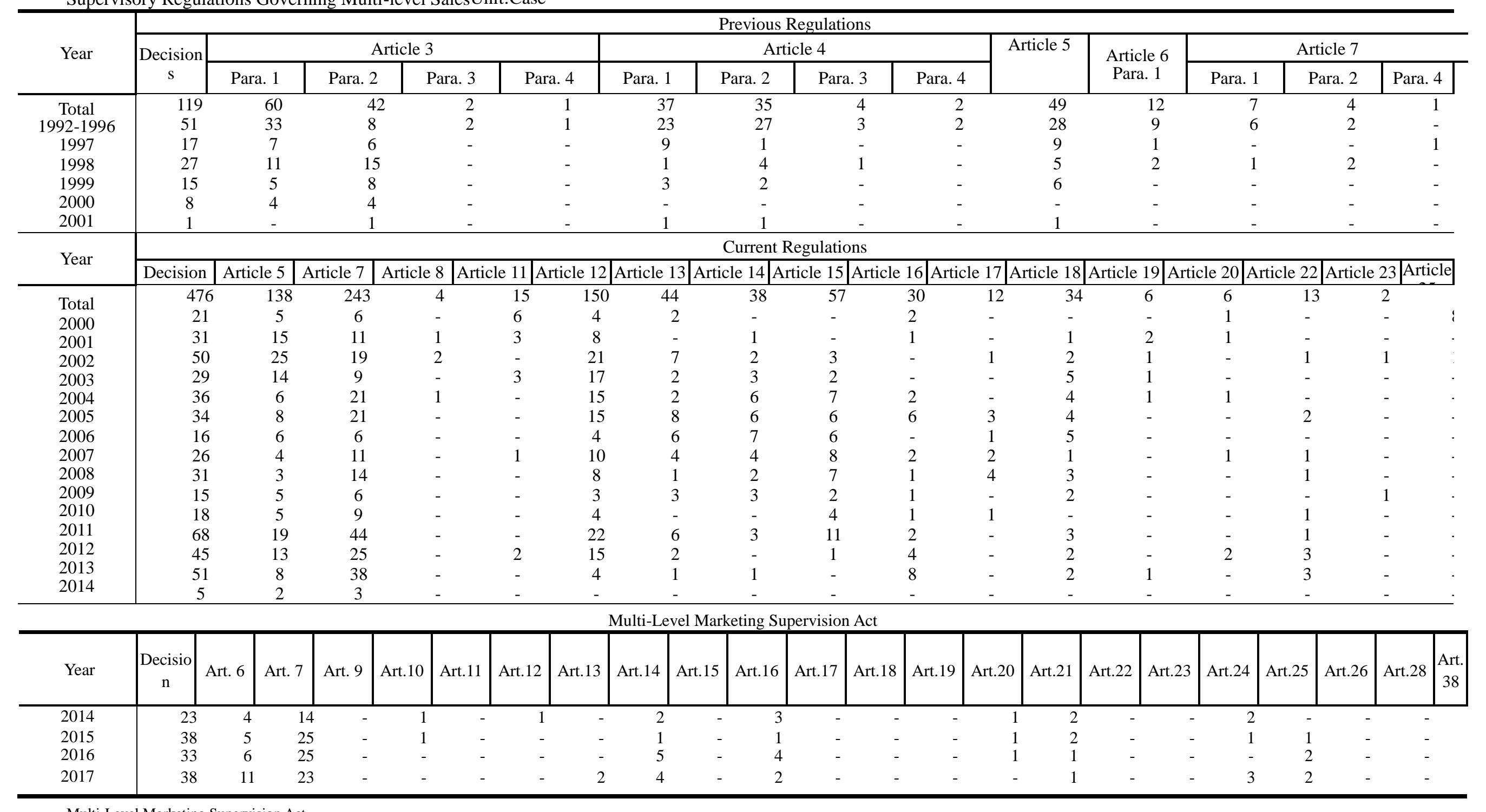

Multi-Level Marketing Supervision Act

Notes: 1. The partialrevision of the Supervisory Regulations governing Multi-level Sales was promulgated on June 16, 1999,and entered into effect on July 1, 1999.

2. Figures may add up to exceed the totalbecause acase of decision ruling may be concerned with violation of more than one articleof SRMS.

Source: Fair Trade Commission(2018b) 